"Access to finance problems for small retail businesses in South Africa: comparative views from finance seekers (retailers) and finance providers (banks)"

\begin{tabular}{|c|c|}
\hline AUTHORS & $\begin{array}{l}\text { Holger J. Schmidt } \\
\text { Roger B. Mason (D https://orcid.org/0000-0001-7927-1767 } \\
\mathbb{R} \text { https://publons.com/researcher/2752201/roger-b-mason/ } \\
\text { Juan-Pierré Bruwer } \\
\text { Jonathan Aspeling }\end{array}$ \\
\hline ARTICLE INFO & $\begin{array}{l}\text { Holger J. Schmidt, Roger B. Mason, Juan-Pierré Bruwer and Jonathan Aspeling } \\
\text { (2017). Access to finance problems for small retail businesses in South Africa: } \\
\text { comparative views from finance seekers (retailers) and finance providers (banks). } \\
\text { Banks and Bank Systems, 12(2), 20-30. doi:10.21511/bbs.12(2).2017.02 }\end{array}$ \\
\hline DOI & http://dx.doi.org/10.21511/bbs.12(2).2017.02 \\
\hline RELEASED ON & Friday, 23 June 2017 \\
\hline RECEIVED ON & Sunday, 26 February 2017 \\
\hline ACCEPTED ON & Friday, 24 March 2017 \\
\hline LICENSE & $\begin{array}{l}(\mathrm{c}) \text { EY-No } \\
\text { This work is licensed under a Creative Commons Attribution-NonCommercial } 4.0 \\
\text { International License }\end{array}$ \\
\hline JOURNAL & "Banks and Bank Systems" \\
\hline ISSN PRINT & $1816-7403$ \\
\hline ISSN ONLINE & $1991-7074$ \\
\hline PUBLISHER & LLC "Consulting Publishing Company "Business Perspectives" \\
\hline FOUNDER & LLC “Consulting Publishing Company "Business Perspectives" \\
\hline
\end{tabular}

NUMBER OF REFERENCES

45

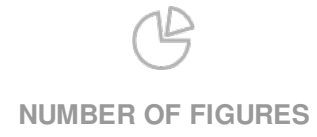

0
NUMBER OF TABLES

3

(C) The author(s) 2023. This publication is an open access article. 
Holger J. Schmidt (Germany), Roger B. Mason (South Africa), Juan-Pierré Bruwer (South Africa), Jonathan Aspeling (South Africa)

\title{
Access to finance problems for small retail businesses in South Africa: comparative views from finance seekers (retailers) and finance providers (banks)
}

\begin{abstract}
Small retail businesses are essential for the growth of the South African economy. Though many of these business entities need more assets to seize business opportunities, previous research studies suggest that their overall access to finance through banks and other finance providers seems to be limited. In general, small retail businesses are usually managed by entrepreneurs who lack financial knowledge, but banks, when deciding on credit applications, rely heavily on financial information, which is provided by these entrepreneurs. Notwithstanding the aforementioned, this study aimed to explore barriers that limit access to finance for South African small retailers, from the perspectives of finance providers (banking institutions) and finance seekers (small retailers). Additionally, measures were highlighted to show how those hurdles could be overcome. Qualitative research was conducted, whereby data were collected via semi-structured interviews with management personnel at banks and other financial institutions, as well as independent experts and small retail business owners and managers. The findings show that many financing opportunities are available to small retail businesses, but access to these opportunities is limited mainly owing to, inter alia, strict bank regulations and factors that are inherent to small retail business owners.
\end{abstract}

Keywords: banks, business finance, financiers, financing institutions, small retail businesses, finance seekers, finance providers.

JEL Classification: G21, L26, L81, L84, M41.

Received on: $26^{\text {th }}$ of February, 2017.

Accepted on: $24^{\text {th }}$ of March, 2017.

\section{Introduction}

Not unusual for the African continent, South Africa's Wholesale and Retail (W\&R) sector is a significant component of the country's economy and a major employer, which provides jobs for an estimated $20 \%$ (3.1 million citizens) of the national workforce (Ndungu and Theron, 2008; Steyn, 2013; W\&RSETA, 2014; Statistics South Africa, 2015). Moreover, the W\&R sector contributes approximately a third to the national Gross Domestic Product (GDP) (Sibindi and Aren, 2015; Dennis and Piatti, 2015), while being responsible for $12.5 \%$ of the annual GDP growth (W\&RSETA, 2014). It is estimated that 75000 retail businesses are formally registered with the W\&R Sector Training Authority (W\&RSETA, n.d.), while more than 100 000 informal (unregistered) retailer businesses are believed to operate accounting for $\pm 10 \%$ of turnover in the W\&R sector (W\&RSETA, 2013). Notwithstanding the aforementioned, about $96 \%$ of W\&RSETA registered retail businesses are classified as small- and

(C) Holger J. Schmidt, Roger B. Mason, Juan-Pierré Bruwer, Jonathan Aspeling, 2017.

Holger J. Schmidt, Ph.D., Prof. of Management \& Marketing, Koblenz University of Applied Sciences, Germany.

Roger B. Mason, Ph.D., Prof. Wholesale and Retail Leadership Chair, Cape Peninsula University of Technology, South Africa.

Juan-Pierré Bruwer, Dr., DTech, Cost and Management Accounting, Cape Peninsula University of Technology, South Africa.

Jonathan Aspeling, MCom, Retail Business Management, Cape Peninsula University of Technology, South Africa.

This is an Open Access article, distributed under the terms of the Creative Commons Attribution-NonCommercial 4.0 International license, which permits re-use, distribution, and reproduction, provided the materials aren't used for commercial purposes and the original work is properly cited. micro sized enterprises (employing between 0 and 50 full time employees), while $3 \%$ are classified as medium sized enterprises (employing between 51 and 200 full time employees) and only $1 \%$ as large enterprises (employing over 200 full time employees) (W\&RSETA, 2014). Hence, these figures imply that $99 \%$ of the W\&R sector's registered retail businesses can be considered to be small, medium or micro sized enterprises (SMEs) (South Africa, 1996).

Considering the importance of SMEs for South Africa's economy not only in the retail sector, but also beyond, it is interesting to note that these businesses are believed to have one of the worst sustainability rates in the world (Fatoki, 2014). This view is supported by the phenomenon that during the early 2010 s, approximately $63 \%$ of South African SMEs closed their doors after being in operation for merely two years (Cant and Wiid, 2013). Two economic factors, which regularly make their appearance as probable reasons to justify the weak sustainability of South African SMEs, among other economic factors, are: 1) limited funds; and 2) limited access to financing opportunities (Iwu et al., 2015). From a managerial viewpoint, the latter factor seems particularly interesting, because without a broader access to finance opportunities, available funds cannot be exploited. This view is supported by theories, which purport that SME management lacks the knowledge to identify available sources of external funding, and/or SMEs have trouble satisfying the loan requirements of banks in order to secure external funding (Chimucheka and Mandipaka, 2015). There is also evidence from practice that supports this notion; according to a recent survey, which 
was conducted among 1423 entrepreneurs, $85 \%$ were found to be self-funded, while $9 \%$ received funding from friends and family and only $2 \%$ funded their businesses with the use of bank loans. The remaining $4 \%$ were funded through the help of governmental institutions or angel investors (Seed Academy, 2016).

This paper discusses the barrier of limited access to finance, which South African small retail businesses experience, whilst considering the different perspectives of banks and other finance providers, and finance seekers. The relevant discussion is organized as follows: Section 1 reviews the literature; section 2 discusses the methodology; section 3 describes the findings, which are discussed in section 4; section 5 offers suggestions for future actions; and the final section discusses the study's limitations and provides some concluding remarks.

\section{Literature review}

Access to finance is considered to be a challenge for many start-up businesses (Seed Academy, 2016), including established SMEs (Lekhanya and Mason, 2014; Jere et al., 2015). The latter is disconcerting (as mentioned above), since it is highly probable that limited access to financing opportunities may have a direct influence on the sustainability of South African SMEs. Quintessentially, the barrier of "limited access to financing opportunities" was identified in the early 1990s for the first time (Weijland, 1992; Hailey, 1992) as an impeding factor on SME sustainability. Since then, this barrier has been highlighted regularly in research studies (see Table 1).

Table 1. Literature review on finance accessibility for SA SMEs

\begin{tabular}{|l|l|}
\hline \multicolumn{1}{|c|}{ Source } & \multicolumn{1}{|c|}{ Results } \\
\hline Kauffmann (2005) & $\begin{array}{l}\text { Access to financing opportunities is poor for SA SMEs because } \\
\text { of the high risk of default. This results in the limited expansion of } \\
\text { these business entities. }\end{array}$ \\
\hline $\begin{array}{l}\text { Grimm and Richter } \\
\text { (2006) }\end{array}$ & $\begin{array}{l}\text { ltthough there is an abundance of financing opportunities for } \\
\text { SA SMEs, wide interest rate spreads and high costs of credit } \\
\text { disqualify many from obtaining external funding. }\end{array}$ \\
\hline Beck et al. (2009) & $\begin{array}{l}\text { SASMEs have limited access to financing opportunities, as } \\
\text { most of Africa's financial systems are characterized by shallow- } \\
\text { ness, high costs, and high interest rates. }\end{array}$ \\
\hline $\begin{array}{l}\text { Chibanda et al. } \\
\text { (2009) }\end{array}$ & $\begin{array}{l}\text { There are low levels of equity and debt capital, while reliance } \\
\text { on government funding is problematic. }\end{array}$ \\
\hline Orobia et al. (2013) & $\begin{array}{l}\text { Taking into account that SASMEs' daily volume of transactions } \\
\text { varies, their net income (in most cases) cannot be guaranteed } \\
\text { to repay debt (external financing). }\end{array}$ \\
\hline $\begin{array}{l}\text { Lekhanya and } \\
\text { Mason (2014) }\end{array}$ & $\begin{array}{l}\text { There are financing opportunities available to SASMEs; } \\
\text { however, these entities do not "cash in" on these opportunities } \\
\text { owing to red tape. }\end{array}$ \\
\hline $\begin{array}{l}\text { Nkonki-Mandleni } \\
\text { and Anim (2014) }\end{array}$ & $\begin{array}{l}\text { The biggest support, which cooperatives and/or small busi- } \\
\text { nesses require in all SA provinces,is financing. }\end{array}$ \\
\hline $\begin{array}{l}\text { Dept of Trade \& } \\
\text { Industry (2015) }\end{array}$ & $\begin{array}{l}\text { The lack of finance is one of government's greatest challenges } \\
\text { for co-operatives and/or small businesses. }\end{array}$ \\
\hline Jere et al. (2015) & $\begin{array}{l}\text { Financing opportunities are available for SASMEs; however, } \\
\text { access is granted to those business entities that can guarantee } \\
\text { returns on investments. }\end{array}$ \\
\hline $\begin{array}{l}\text { Kanyane and } \\
\text { Ilorah (2015) }\end{array}$ & $\begin{array}{l}\text { The lack of financial support is a limiting factor, which adversely } \\
\text { impacts the sustainability of cooperatives and/or small busi- } \\
\text { nesses. }\end{array}$ \\
\hline
\end{tabular}

Although many studies have reported on the limited access to financing opportunities as a major barrier for South African SMEs, it is apparent that these publications (Table 1) are not clear as to what this barrier actually entails - the barrier of "limited access to financing opportunities" can be widely interpreted. To place this in perspective, the access to finance problem is briefly discussed in terms of two theories, as outlined below.

- Finance gap theory: It is probable that there is a limited access to financing opportunities, as SMEs often find external funding opportunities more costly and less available and/or accessible (Vos and Forlong, 1996). This can be as a result of, inter alia, high finance costs, agency costs, and complex red-tape (Scherr et al., 1993; Timm, 2011).

- Resource dependence theory: It is probable that there is a limited access to financing opportunities, as SMEs have limited relationships with external parties in order to secure financing (Connelly et al., 2011). As a result, they are predominantly dependent on internal stakeholders to provide monetary resources so that they can remain in operation (Davis and Cobb, 2010).

Though there might be other (more detailed) reasons why South African SMEs have limited access to financing opportunities, like their own financial abilities or their personal attitudes, both theories shown above are quite feasible. This notion is supported by previous research (Timm, 2011; Raap and Mason, 2014; Department of Trade and Industry, 2015; Meyer, 2015), which shows that there are ample financing opportunities available for South African SMEs, both from the South African government and from South African commercial banks (PMG, 2012). Despite the availability of these funding opportunities, they are subject to complex redtape, which should be adhered to before finance can be granted (Cassidy, 2016; Timm, 2016).

Stemming from the above, there are at least three good reasons to examine the barrier of limited access to financing opportunities from a retail perspective. First, though the inference can be made that South African SMEs' sustainability may be adversely influenced by limited funds, which, in turn, is spurred on by a limited access to financing opportunities, it is not clear what constitutes this barrier; whether it is based on real phenomena or merely on personal perceptions. Second, too little is known about the potentially differing perceptions of finance providers and finance seekers in respect of finance accessibility. So far, these different perspectives have never been discussed in a single study. Third, there has not been a study that analyzes finance accessibility with a predominant focus on the W\&R sector. 
Therefore, within the ambit of this research study, the following research question was investigated: What does the barrier of limited access to financing opportunities entail from the perspectives of finance providers and finance seekers in the context of South African small retail businesses?

\section{Research method and design}

2.1. Study design. Since the objective of this research study was to gain insights into the identified research problem, and to discover basic social processes in the collected data, it was exploratory in nature. A qualitative research approach was followed, which entailed acquiring detailed and rich data (Kauppinen-Räisänen and Grönroos, 2015) through the use of personal interviews. This research method is deemed as being appropriate to explore phenomena in depth, and to obtain frank insights (Rowley, 2012).

Fundamentally, the research methodology was strongly influenced by grounded theory (Glaser and Strauss, 1967) in terms of a simultaneous collection and analysis of (qualitative) data, and a creation of analytic codes and categories, which were inspired by pre-existing conceptualizations, but were finally developed from the data (Charmaz, 2006). A multiperspective approach to assess the accessibility of financing opportunities for small retail businesses was adopted by interviewing managers from banks and other financial institutions, independent financial advisors and industry representatives (referred to as finance providers), as well as small business owners and management (referred to as finance seekers) in the W\&R sector. This approach provided assurance in terms of sufficient coverage (broad) in relation to the research topic.

2.2. Data collection and sampling. A mixture of non-probability sampling techniques was used to obtain data. Convenience and snowball sampling were mainly used in conjunction with one another, though an element of judgmental sampling was also incorporated. This was especially done to ensure that participants came from a range of different business entities, and had different positions and personal backgrounds (Marshall, 1996).

Regarding finance providers, a total of 16 respondents were interviewed. The sample included seven bank managers from five different banks, three financial managers from two different financial institutions, two managers who were based in a governmental agency, two independent financial advisors and two retailing experts. Most interviewees were identified via the Internet and approached via e-mail with a letter of recommendation and a short description of the study's objectives attached. Some of the respondents were invited to take part in this study upon the recommendations of other interviewees.
All interviewees had several years of experience in the banking and/or retailing industries, and claimed to have a good understanding of small retail businesses in relation to their accessing of financing opportunities. Two of the interviewees were interviewed in one common session, while the others were interviewed individually, either personally, or via telephone or Skype.

For (potential) finance seekers, a total of 20 people were interviewed, of whom the majority were SME retail business owners; the remainder comprised SME retail business managers. The retail businesses represented a range of retail segments (e.g., fashion, ceramics, interior design, furniture, lights, spices, liquor, groceries, and fuel); and only one was a pure wholesaler without any business offered to endusers (individual consumers). A majority of the businesses were small retail businesses that employed between five and 50 full time employees. Only a few had less than five employees. As in the case of the finance providers, some of the interviewees were identified via the internet and approached via e-mail. Most of the participating interviewees were identified by "walk-ins". All of the participants received a copy of the letter of recommendation and the project specifications. All the interviewees were interviewed personally; ten by one researcher, three by a second researcher, and seven by a team of the first researcher and a third one.

During the interviews, a semi-structured interview guide, which contained open-ended questions, was used, which was developed from the literature. The interview guidelines were further developed and adjusted, as more insights evolved during the data collection phase. All the data were consolidated and later analyzed. The finance provider interviewees were requested to answer all questions with reference to a typical 'very small' to 'small' retailer, which employs between 5 and 50 persons. The finance seeker interviewees were asked to describe their own experiences and opinions. All of the interviews were recorded and subsequently transcribed.

All of the interviews took place between May and June 2016. The average interview lasted for approximately 30 minutes with the finance providers, with a spread of between 20 and 49 minutes. For the potential finance seekers, interviews lasted about 18 minutes, with only three lasting for less than 10 minutes and the longest lasting for 31 minutes.

2.3. Data analysis. The transcriptions of interviews were uploaded to a PC and were analyzed by using the software atlas.ti (version 7.5.11). Data analyses, then, encompassed various phases (KauppinenRäisänen and Grönroos, 2015): firstly, about a quarter of the interviews were analyzed individually, and coded according to a pre-developed coding scheme, 
which was continuously adapted and improved, as more interviews were analyzed. Secondly, findings relative to the themes across the already analyzed interviews were compared, which helped to achieve a better understanding of the different perspectives. Thirdly, the remaining interviews were analyzed, whilst the codes were continuously improved; and, finally, the analysis was brought together to a conclusive summary in the fourth and final step.

\section{Findings}

This section presents the findings and a discussion of these in relation to the study. Whenever a direct quote from one of the interviews is stated, it is indented and displayed using an italic font. To differentiate the words of the finance providers and experts from those of the SME retail business owners and/or managers, the former were marked with an "F" and the latter with an "R".

3.1. Barriers to growth. Obviously, a retailer should know the basics of how to manage a business, if the business is to grow. These basics include, inter alia, financial knowledge, competences in marketing and brand building, the ability to build a positive relationship with suppliers and compliance with legal requirements. The interviewees identified several of these basics as general hurdles to growth and, hence, did not show much confidence in small retailers' individual competences and abilities.

"I think one of the biggest obstacles is definitely that they have no clue about their numbers" $(F)$.

"My opinion is that the finance administration and marketing would be the biggest hurdles that a SME or a small business or a retailer would have to overcome" $(F)$.

According to the interviewees, apart from the general barriers to growth, there are different, more specific obstacles that hinder the growth of small retailers in SA. Not surprisingly, one of them is the current economic situation, which is characterized by high interest rates, a weak rand and consumers who are reluctant to buy. In a highly competitive environment, with large investments in inventory, traditionally small retail margins, but high rents and a high demand for attractive retail outlets, it becomes increasingly difficult for small retailers to survive. The unstable political situation in 2015 and 2016 did not help to build (business) confidence. Additionally, some of the finance providers also saw theft, fraud and general ethics as factors that hinder SA retailers' growth. Deficiencies in infrastructure and public transportation, as well as the lack of reliable and fast access to mobile communications and to the Internet, were also among factors that were considered to prevent small retailers' growth.
Connected to the disappointing growth rates of small retailers could also be the attitude of some of the business owners, as described below:

"Okay, my business can become big. No, no, let's just keep it small. It's too stressful" (F).

More closely related to the actual topic of this research are the interviewees' opinions that access to finance can also be a major growth obstacle for small retailers.

"I think with, in the last couple of years specifically, it's been very difficult to get finance for small businesses in South Africa" ( $R$ ).

3.2. Small retailer's financial knowledge. It is obvious that small business owners are not fully aware of all the financial instruments that might be available to them. The interviewed finance managers perceived that banks are still seen to be the most powerful providers of finance; alternative funding opportunities, by way of private companies outside of the banking sector and governmental support agencies, are less known to small retailers. The retailers tend to agree that their degree of information is insufficient.

"No, it's the financial instruments that are available that a lot of small businesses don't understand and don't know how to actually utilize and that's where we go to the market and we educate them" $(F)$.

"The knowledge of what's available (is a big problem). Like I said, I don't actually know what else is available. My dad likes (name of bank), so you go to (name of bank)" (R).

A lack of knowledge of available finance is one thing and maybe considered as being of lesser importance, since transparency can never be $100 \%$. More worrying though is that banking people - and even some of the retailers themselves - pointed out the poor financial knowledge of many business owners in the retail industry. One of the major deficiencies might be the widely accepted perception that a business owner should not show his/her true earnings in his financial statements.

"Every SME guy heard somewhere, somebody told him, or his friend around the braai that the best thing to do is you do not [unclear], you should not make money. Your financials must always be in the negative. There must be losses. This is very wrong because from the funder's side, how do you fund a business that's making losses?" (F).

"We're not recording everything the way we're supposed to record it. We are not doing the right transactions where they're supposed to be. So it's such things that make us look like we don't really qualify for funding" (R). 
Another issue is the poor financial education of some business owners and entrepreneurs who started their retail business from scratch.

"I think one of the biggest obstacles is definitely that they have no clue about their numbers" (F).

3.3. General availability of financing opportunities. The interviewees see a big range of financial instruments that a small retailer could choose from theoretically. These instruments include banking products such as a transactional account with an overdraft possibility, term loans, secured or unsecured, for a business or private person, surety bonds, which often are registered over a person's immovable property, and other insurance, saving and investment products. These instruments could be used to finance trading (buying goods), vehicles and assets, and to provide working capital. For retailers that trade internationally, banks also provide letters of credit or forward exchange cover. Other finance instruments, which are usually not provided by banks, but by other financial institutions, include factoring and invoice discounting, as well as loans that are not interest bearing, but are based on turnover or on a base that the entrepreneur controls better.

For small retailers, an additional, important source of finance is the supplier. In addition, a small retailer could have access to venture capital, which is provided by corporate shareholders or private business angel investors, to governmental funding or to sources of informal lending. There is of course always a possibility that friends and/or family could also be a source of finance.

The broad spectrum of financial instruments would not help a small retailer if, from a general viewpoint, there was not enough finance available for them. Interestingly, there does not seem to be a shortage on the side of finance offers: there appears to be plenty of finance opportunities, which are available for small retailers, especially if they have been in business for some time and were able to establish an operational track record.

"We've got a good relationship, fortunately, with the bank in terms of getting finance. But also, having said that, if you're in the market for over 20 years and you've got a stable record, then, the banks will easily accommodate you" ( $R$ ).

"There's plenty of money. There's plenty of funding available but how do you get it there?" (F).

Some of the interviewees pointed out that a shortage of money does not seem to be the problem, but rather the small retailer's ability to access the available finance at reasonable costs, especially when a small retailer is new in the business. This also implies that there is a shortage of available finance at reasonable costs if one cannot meet the criteria that financial institutions require.

"For established retailers, they do have access to finance but finance is not cheap" $(F)$.

"Can't think of their names, but on a daily basis, I'm being offered loans probably at a $25 \%$ repayment" $(R)$.

3.4. Small retailer's ability to access available finance. Overall, access to available finance, generally, seems to be a real problem for small retailers.

"I think with, in the last couple of years specifically, it's been very difficult to get finance for small businesses in South Africa" (R).

"They (the banks) make it very difficult for you. (...) Banks don't want to borrow money to people" (R).

It would appear that mostly new businesses seem to struggle to access finance. There was a common understanding among interviewees that this referred to retailers that had recently entered the market, or that had not been in business for a longer period of time, since retailers that failed to provide a proven track record faced the biggest hurdles to access available finance. The business should be established at least more than one year to stand a fair chance to access finance, while some institutions and banks even insist on requesting two years.

"... access to funds, it is a problem. I'm not going to lie about that, for the first year" $(F)$.

"So if you're a complete new start up, you're going to find it incredibly difficult" $(F)$.

The legal requirements seem to be a smaller problem. Banks and other financial institutions are regulated by the National Credit Act (NCA) and other legislation such as the Financial Advisory and Intermediary Services Act, the Financial Intelligence Centre Act and Basel. These rules aim to make banking more transparent and demand that corresponding institutions act as responsible lenders. This implies that banks cannot provide credit to businesses that cannot afford to pay it back. Hence, a process of due diligence is conducted before they approve credit applications. This means that it is easier for businesses that have a track record to access finance.

"It's more, normally the NCA, you know, the National Credit Act. You know, you need to prove affordability before you can, you need to be a responsible lender" $(F)$.

"In terms of the NCA as well, you know, you need to prove affordability and you can only prove affordability if you've got a good track record" (F). 
A more valid reason for retailers' difficulties to access financial instruments such as loans can be seen in the requirements and standards, which are set by banks and other financial institutions. As a basic requirement, a business should be registered and have a bank account in order to access finance. Then, in addition to the usual business documents, which include financial statements, management accounts, tax clearance certificates and owners' CVs, their personal credit records and a synopsis of the business, providers of finance will ask for proof of the owner's expertise, a positive track record, a convincing business plan with a cash flow projection and underpinning securities. The latter makes it particularly difficult for small businesses to obtain access to finance and to grow, as the following statement suggests:

"Unless you can put surety down, you're not going to get money, no chance" (R).

A lot of time is required to prepare all documents to apply for finance, and without the help of external advisors and accountants, the owner of a small retailer will hardly be able to comply with the requirements. This also means that to access finance, small retailers need finance to pay their advisors. Bank managers and retailers themselves seem to agree on this point, as the following response demonstrates:

"The requirements that are needed are way too complicated for a small retailer to attend to themselves and, therefore, require the input or the assistance by an expert, such as an accountant or a company that is specializing in drafting of business plans. (...) It could end up between R10 000 or even up to R20 000 of costs for the retailer before they even obtain the finance" $(F)$.

Another problem seems to be that the requirements to obtain access to a loan are too standardized everybody is treated the same, irrespective of their personal background. This makes it difficult, if not impossible, for certain people to obtain credit from a formal institution, as the following statements imply - the first response is from a bank's perspective, while the second is from a retailer's perspective:

"I'll be the first one to say, look, banks are not doing enough to help, especially entrepreneurs from the townships" $(F)$.

"I think they use certain standard requirements for each and every individual, whether you are a big or small business" ( $R$ ).

Nevertheless, the finance experts also identified two reasons, which are typical of an owner of a small retail business and, which prevent them from meeting these requirements. Many seem to be reluctant to take risks, as they are not willing to provide securities even if they were in a position to do so. And many business owners do not appear to be on top of their financials, which makes them dependent on expensive external help when they apply for finance:

"A lot of them don't have that (financials and the management accounts). A lot of them trade for about three, four years, you know and you ask it from them, they will take another half a year or maybe even more to get it (...)" $(F)$.

"A lot of the guys will say, 'I don't want to. I don't want to sign personal surety' and, then, we can't give them the funding" $(F)$.

While the banks may perceive that small retailers are reluctant to take risks by not applying for financial aid, these businesses may interpret their decision or choice differently. This decision may be owing to the small business owner's personality, his/her entrepreneurial spirit and, hence, strong desire to remain independent, and an aversion to general paperwork and administrative tasks that may accompany this money lending process. Two of the small business owners who did not want to apply for financial loans stated the following:

"Because I'm very independent and I don't want the ties. (...) You probably have to put forward a business plan and a lot of paper work. No, because the less of that in my life the better; it's already too much" (R).

"I just hate owing money" (R).

Considering the application process, respondents from the banks declared that it is simple, while results are received in a short space of time following the application.

"I think it is an opinion out there that it takes too long. But you will see that specifically for a retail transactional banking (...), where you can do online applications. You get an answer in five days" $(F)$.

The retailers disagreed with this perspective, and criticized the length of time that banks take to inform applicants of the outcome of their credit applications:

"If I tell you, it took me 12 months, 12 months to finally get them to agree to loan me an amount of money that is laughable" ( $R$ ).

The interviewees identified other reasons why small retailers do not apply for finance. Some of them more likely those who have an informal background might generally feel uncomfortable to approach banks, while others might not expect the banks to assist them and, therefore, do not want to invest time in something that they believe will not amount to anything.

"The biggest obstacle is maybe still that if I start a small, small business, I'm scared to go to the bank" (F). 
"Banks are terrible places; we all know that, don't we? Isn't that the truth?” (R).

"Everybody is saying you can't get a loan to start a business" (R).

3.5. The role and performance of governmental support agencies. Overall, the finance providers stressed the importance of governmental support agencies such as SEFA (Small Enterprise Financing Agency), SEDA (Small Enterprise Development Agency) and the Industrial Development Corporation (IDC) in developing and promoting small businesses.

"I think they have a huge, important role to play and they do have the means to do it" (F).

However, those agencies do not seem to react as quickly as they should, and it is not always clear who would qualify to apply and what would be required when applying. Though there may have been improvements during recent years, there is plenty of criticism regarding their efficiency.

"The mind-set of an entrepreneur is seeing an opportunity, taking the risks and going with it. But it's normally time-sensitive; be it weeks or be it a month or two. So if an application process takes six months to fulfil, often the opportunity has dissipated" $(F)$.

"So, keep in mind South Africa has over 70 different programs available and I'm sure you've seen that each program has 20 pages of rules and regulations. To make a little bit more fun, one page of exemptions" $(F)$.

White retail business owners also perceive that governmental support agencies use race as a criterion when allocating funding to applicants. One small retail business owner stated the following when probed for reasons why they would not apply for financial support at the SEFA or any other governmental support agencies:

"... the only thing that I can say from the heart, it's either you're too white or you're too black or you're too colored (...)" (R).

\subsection{Proposals for improved access to finance.} The finance providers and finance seekers provided several ideas of how to improve access to finance. A first group of recommendations concerns the application process, and the methods that banks use to prequalify a retail business. Some perceive that this process must be done more holistically, using innovative information systems, and should contain a strong view of the business owner's personality and capabilities.
"How do we confirm your status in your community, are you trusted? Are you not trusted? Would that give us a better reading on your repay ability or propensity to repay it? How do you create partnerships versus pure funding models?" (F).

"I do think we need to create more of a digital environment because the costs of face-to-face business are too high. (...) I think we need to create a far different digital solution for small entities to access a trusted environment by revealing more of themselves" $(F)$.

Other recommendations included sharing of risks in commonly managed funds, being more flexible around the conditions of loans, finding ways to better understand clients' needs, and accompanying and mentoring small retailers more intensely during the period that is required to pay back loans.

Government should also look for new ways to support small retailers. The following quote gives examples of what the state could do, other than providing funds:

"So things must be more transparent and the government needs to give a support system, where you can actually go, where you can find out, where you can enquire, where you can be helped" ( $R$ ).

There was also the view that small retail businesses should change their business strategies in order to make it easier for financial institutions to give them access to finance. One recommendation was to establish stronger bonds amongst retailers themselves in the form of partnerships or industry cooperatives.

"I think having some other, making sure that they have a buying power, put them together in groups that they buy together, would increase their margin and gives them easier possibility to grow" $(F)$.

A last area of improvement concerned the marketing of available funding:

"From my point of view, I think, as financial institutions, we need to inform more. We need to advertize more about what is available. Let's eliminate the level of discomfort" $(F)$.

Some of the interviewees perceived the small retailers' financial knowledge and ability as being a decisive hurdle, which challenges their growth. The finance and retail experts also perceive the need to train and educate small business owners around financial matters, as well as general business knowledge. The retail business owners concurred, as they also identified that they may need to improve on their financial education.

"I think number one is definitely trained people; offer them some sort of mentorship, especially so that they learn how to have their numbers in control" $(F)$. 
Quite a few of the experts stressed the importance of establishing a business angel network in SA. This seems imperative, especially when considering that new retail businesses, compared to established players, have limited opportunities to access finance because of their missing track record:

"And, so if, you have a good Angel Investor Network, there's people that are willing to risk their capital and (...) in South Africa you don't really have that Angel Network" (F).

Finally, there was the view that successful SA business leaders should be more involved in mentoring programs and governmental efforts that assist small retailers:

"If big business and big business leaders would mentor the smaller guy as a social responsibility or as a pay back to having, they've achieved whatever they've achieved, they could get into the government organizations and sort of speed up those processes and give them good advice" (F).

\section{Discussion}

The above results justify that the views of the finance providers, including experts and potential finance seekers that have a retail background, on the accessibility of financing opportunities for small retail businesses are similar in some respects, while they are different in others. They also confirmed the suggestions, which were proposed by the two finance theories in the literature review. They confirmed the difficulties that complex redtape pose (e.g., bank and government application procedures), as suggested by the Finance Gap theory (Scherr et al., 1993; Timm, 2011), and the difficulties that the Resource Dependence theory pose, namely limited relationships with external parties (e.g. banks, suppliers) to secure finance (Connelly et al., 2011), which results in reliance on personal financing by friends and relations (Davis and Cobb, 2010). Table 2 below outlines the research study's respondents' views in respect of the major arguments that the study presents.

Table 2. Outline of the views of finance providers and seekers

\begin{tabular}{|c|c|c|}
\hline Question & Finance providers (banks) & Finance seekers (small retailers) \\
\hline Is finance a major growth obstacle? & $\begin{array}{l}\text { Access to finance is a problem for start-ups. For estab- } \\
\text { lished businesses, it is not a major growth obstacle. }\end{array}$ & Access to finance is one of the most important barriers to future growth. \\
\hline $\begin{array}{l}\text { Are there enough finance opportunities } \\
\text { available? }\end{array}$ & There is plenty of finance from various sources available. & Knowledge about available finance opportunities is too limited. \\
\hline $\begin{array}{l}\text { Does small retailers' education hinder their } \\
\text { access to finance opportunities? }\end{array}$ & $\begin{array}{l}\text { The financial knowledge of small retail owners is generally } \\
\text { very limited, which often leads to wrong decisions about } \\
\text { how to run the business. }\end{array}$ & $\begin{array}{l}\text { The smaller the business, the more limited the financial knowledge of } \\
\text { the owner. Financial knowledge would be "nice to have", but entrepre- } \\
\text { neurs can't be finance experts. }\end{array}$ \\
\hline $\begin{array}{l}\text { Are finance providers' standards to access } \\
\text { finance too high for finance seekers? }\end{array}$ & $\begin{array}{l}\text { It is true that many standards have to be met, but this is } \\
\text { because banks have to be responsible lenders. }\end{array}$ & $\begin{array}{l}\text { Too many requirements limit the access to finance, especially for start- } \\
\text { ups. Specifically the bank's need for collateral limits access to finance. }\end{array}$ \\
\hline $\begin{array}{l}\text { Does the application process hinder } \\
\text { finance seekers from accessing available } \\
\text { finance opportunities? }\end{array}$ & $\begin{array}{l}\text { The application process for bank loans is lean, and results } \\
\text { can be provided quickly. }\end{array}$ & It is lengthy, admin intense and complicated. \\
\hline $\begin{array}{l}\text { What role do government agencies play in } \\
\text { financing the growth of small retailers? }\end{array}$ & They definitely play an important role. & If managed properly, they could play an important role. \\
\hline How do governmental agencies perform? & $\begin{array}{l}\text { Many things have been done, but there is still room for } \\
\text { improvement. }\end{array}$ & $\begin{array}{l}\text { They act bureaucratic. Access to public funding depends too often on } \\
\text { colour, gender and age. }\end{array}$ \\
\hline $\begin{array}{l}\text { How can the relationship between finance } \\
\text { providers and seekers be described? }\end{array}$ & $\begin{array}{l}\text { Small retailers are growth engines and therefore an } \\
\text { important market. Financial institutions see themselves as } \\
\text { partners of the retailers. }\end{array}$ & $\begin{array}{l}\text { A good relationship with finance providers is essential, but it depends on } \\
\text { the bank's local relationship manager. Often, banks are not trusted. }\end{array}$ \\
\hline
\end{tabular}

This summary of the findings and discussion shows that the ubiquitous "limited access to funding" problem, as experienced by small retail businesses, can be better understood as a function of the following barriers:

- The problem is mainly experienced by smalland micro-enterprises, rather than by mediumsized enterprises.

- There are several financing opportunities, which are available for SME retail businesses, but a number of barriers prevent access to them.

- Small and micro retail business owners lack financial knowledge to successfully access available finance.
- The standards and requirements of finance providers are too complicated for small retail business owners who lack proper financial knowledge.

- Although finance providers believe that their application processes are simple, they are still perceived to be too complicated for those who have limited financial knowledge.

- Although government agencies are positive sources of financing for SME retail businesses, their application processes are perceived to be excessively bureaucratic, and not always transparent or fair.

To overcome these barriers, action should be taken by all stakeholders that are involved in the financing process. 


\section{Suggestions to overcome the barriers}

Table 3 below presents means that can be used by the three major stakeholder groups, namely banks and financial institutions, small retailers and their associations and government to improve accessibility to finance, and, hence, overcome related barriers.

Table 3. Suggestions for stakeholders to overcome barriers to access to finance

\begin{tabular}{|c|c|c|}
\hline $\begin{array}{l}\text { Banks and financial } \\
\text { institutions }\end{array}$ & $\begin{array}{l}\text { Small retailers and } \\
\text { their associations }\end{array}$ & Government \\
\hline $\begin{array}{l}\text { Develop new } \\
\text { approaches to } \\
\text { pre-qualify re- } \\
\text { tailers during } \\
\text { the application } \\
\text { process } \\
\text { Make a more } \\
\text { concerted ef- } \\
\text { fort to adapt to } \\
\text { the needs of } \\
\text { small retailers } \\
\text { by developing } \\
\text { tailored, inno- } \\
\text { vative products }\end{array}$ & $\begin{array}{l}\text { Improve } \\
\text { education and } \\
\text { financial knowl- } \\
\text { edge } \\
\text { Improve } \\
\text { relations with } \\
\text { suppliers } \\
\text { Establish } \\
\text { industry part- } \\
\text { nerships }\end{array}$ & $\begin{array}{l}\text { Improve efficiency and speed } \\
\text { up application process } \\
\text { Improve marketing of institu- } \\
\text { tions and available funds } \\
\text { Find ways to support the } \\
\text { training and education of small } \\
\text { retailers } \\
\text { Support the establishment of } \\
\text { mentoring programs and of a } \\
\text { strong business angel network } \\
\text { in SA } \\
\text { Provide guarantees to finance } \\
\text { providers that lend to small re- } \\
\text { tailers }\end{array}$ \\
\hline
\end{tabular}

Table 3 above illustrates that each of the stakeholders has a responsibility to improve access to finance for small retail businesses. Banks and financial institutions should review their application procedures, especially with small retailers in mind, developing such new procedures in conjunction with retail associations. Similarly, government support agencies should review their application processes to make them more efficient and to promote their services more vigorously to the small retailers. Small retailers themselves should commit to improving their financial knowledge and understanding and make a concerted effort to build relationships with banks, suppliers and others in the industry, so that they are proactive in their search for finance. Finally, a truly successful approach to accessing finance for small retailers will involve considerable and on-going collaboration amongst all stakeholders. For example, banks and government support agencies should provide training and mentoring programs, which small retailers should commit to by attending them, participating in them and applying the skills that they learn there.

\section{Limitations and recommendations}

6.1. Limitations of study. Due to restrictions as a result of the available budget, this study has some limitations that should be considered. In addition to problems that most qualitative research experiences such as a lack of representivity or biased interpretation of the researcher (Snape and Spencer, 2013, p. 4), there are three further shortcomings that are specific to this research design. First, a majority of the interviewees, both finance providers and seekers, were based in the Western Cape. Therefore, the study cannot claim to include relevant views from a holistic SA perspective.
Second, retailing is a broad field that should be divided into subcategories (Zenteset al., 2012, p. 3), each of which follow different strategies and have different customs, rules and regulations. Hence, a study that is as broad as the one represented here can never claim to explain "the retail industry". In terms of access to finance, one can assume that, for example, a liquor retailer in a township would face different problems than an electronic retailer in the city centre (e.g., Berger and Udell, 2004, p. 2). Last, not all of the retailers who were interviewed were actually in need of finance. Since it could be argued that small businesses that are in need of finance have different characteristics and views on the accessibility of finance than firms that do not need finance (Cole and Sokolyk, 2016), future studies should include this criterion in their sample.

6.2. Contribution of the study. This study has contributed to knowledge of small businesses, especially small retailers, by broadening the study from mere availability or access, to a better understanding of the roles and perceptions of banks and other finance providers and finance seekers (retailers), from both a supply and a demand perspective. Furthermore, rather than merely adopting the usual quantitative approach, the qualitative study has provided a much richer picture of the problems and barriers, which both the small retailers and the banks and other financial institutions face in trying to arrange finance for this important sector. It has also highlighted specific problems that should be addressed, both within the small retailers and the banks, and has provided specific suggestions to eliminate these barriers. A final contribution has been identification of the need for cooperation and action from the triumvirate of stakeholders (finance providers, finance seekers and government).

6.3. Recommendations for further research. Since the study has obtained insights into different perspectives from banks and other finance providers and finance seekers, there should be enough information to be able to develop a suitable questionnaire for a quantitative study, which represents a specific retail segment within SA. This questionnaire could, then, be used in different segments to compare individual needs within the industry. Considering a quantitative analysis, based on this exploratory study, the following are empirical propositions for analysis:

small retailers' ability to access funding opportunities:

- depends on their general financial abilities;

- depends on their ability to build and maintain relationships with the banks, the financial community and suppliers;

- depends on their attitude to growth; and

- is influenced by the efficiency of programs that are initiated by governmental agencies. 


\section{Conclusion}

Although access to finance may not be the only growth obstacle for small retailers in SA, it is certainly a serious one. Access to financing opportunities for South African small retailers is limited even from the perspective of bank and finance managers. Some of the major reasons are inherent to small retailers, while others are attributed to the banks and other financial institutions and governmental support agencies.

Overall, the findings have shed some interesting light on the accessibility of finance. There are indications that, if banks, other financial institutions and governmental agencies make money more easily available, it may not necessarily result in further growth. In the same vein, the managers of SA small retailers often lack the financial knowledge to make the right business decisions. Hence, since these business entities do not have proper paper trails, many banks regard them as being risky.

In order to overcome the challenges that small retailers face when trying to access available financing opportunities, it seems that a number of measures should be implemented in a common effort by all the relevant stakeholders. These measures include, inter alia, new approaches to pre-qualify retailers during the application process (especially by banks), improved financial education for retailers and the establishment of mentoring programs and strong business angel networks in SA.

\section{References}

1. Beck, T., Fuchs, M. J., and Uy, M. (2009). Finance in Africa - achievements and challenges. World Bank Policy Research Working Paper Series.

2. Berger, A. N., and Udell, G. F. (2004). A More Complete Conceptual Framework for SME Finance. Retrieved from $\mathrm{http}$ //s3.amazonaws.com/academia.edu.documents/30485727/financing_framework_berger_udell.pdf?AWSAccessKey Id=AKIAJ56TQJRTWSMTNPEA\&Expires=1466425690\&Signature=-NbXwaQAnniSUjsjgLEfs9HcAnto\%3D\&respo nse-content-disposition=inline $\% 3 \mathrm{~B} \% 20$ filename $\% 3 \mathrm{DA} \_$more_complete_conceptual_framework_for.pd (accessed: 20 June 2016).

3. Cant, M. C., and Wiid, J. A. (2013). Establishing the challenges affecting South African SMEs. The International Business \& Economics Research Journal (Online), 12(6), 707.

4. Cassidy, S. (2016). SMEs look to Gordhan's budget to cut red tape. Retrieved from http://www.iol.co.za/business/budget/smes-look-to-gordhans-budget-to-cut-red-tape-1987229 (accessed: 6 April 2016).

5. Charmaz, K. (2006). Constructing Grounded Theory: A Practical Guide Through Qualitative Analysis, Introducing Qualitative Methods Series. London, Sage.

6. Chibanda, M., Ortmann, G. F., and Lyne, M. C. (2009). Institutional and governance factors influencing the performance of selected smallholder agricultural cooperatives in KwaZulu-Natal. Agrekon, 48(3), 293-315.

7. Chimucheka, T., and Mandipaka, F. (2015). Challenges Faced By Small, Medium And Micro Enterprises In The Nkonkobe Municipality. The International Business \& Economics Research Journal, 14(2), 309.

8. Cole, R., and Sokolyk, T. (2016). Who needs credit and who gets credit? Evidence from the surveys of small business finances. Journal of Financial Stability, 24, 40-60.

9. Connelly, B. L., Ketchen Jr, D. J., and Slater, S. F. (2011). Toward a "theoretical toolbox" for sustainability research in marketing. Journal of the Academy of Marketing Science, 39(1), 86-100.

10. Davis, G. F., and Cobb, J. A. (2010). Resource dependence theory: Past and future. Research in the Sociology of Organizations, 28(1), 21-42.

11. Dennis, A., and Piatti, D. (2015). African Powers of Retailing: New horizons for growth. Retrieved from http://www2.deloitte.com/content/dam/Deloitte/ng/Documents/consumer-business/ng-african-powers-of-retailingnew-horizons-for-growth.pdf (accessed: 24 August 2016).

12. Department of Trade and Industry. (2015). SME development financial assistance. Retrieved from https://www.thedti.gov.za/financial_assistance/financial_incentives.jsp?subthemeid=8 (accessed: 22 June 2015).

13. Fatoki, O. (2014). The Perception of New Small Business by Trade Creditors in South Africa. Mediterranean Journal of Social Sciences, 5(16), 27.

14. Glaser, B. G., and Strauss, A. L. (1967). The discovery of grounded theory: Strategies for qualitative research. New York, Aldine de Gruyter.

15. Grimm, J., and Richter, M. (2006). Financing small-scale irrigation in sub-Saharan Africa. Eschborn, World Bank.

16. Hailey, J. (1992). The politics of entrepreneurship-affirmative-action policies for indigenous entrepreneurs. Small Enterprise Development, 3(2), 4-14.

17. Iwu, C., Gwija, S., Tengeh, R., Cupido, C., and Mason, R. B. (2015). Project 2015/18: The unique role of the survivalist retail entrepreneur: Job creation, poverty reduction and educational and training needs. Cape Peninsula University of Technology, Wholesale and Retail Leadership Chair, Cape Town.

18. Jere, M., Jere, A., and Aspeling, J. (2015). A study of small, medium, and micro-sized enterprise (SME) business owner and stakeholder perceptions of barriers and enablers in the South African retail sector. Journal of Governance and Regulation, 4(4), 620-630.

19. Kanyane, M. H., and Ilorah, R. (2015). The cooperative landscape in South Africa: analyzing critical issues. Africa Today, 61(3), 2-14.

20. Kauffmann, C. (2005). Financing SMEs in Africa. African Economic Outlook, 7(1), 1-4. 
21. Kauppinen-Räisänen, H., and Grönroos, C. (2015). Are service marketing models really used in modern practice? Journal of Service Management, 26(3), 346-371.

22. Lekhanya, L. M., and Mason, R. B. (2014). Selected key external factors influencing the success of rural small and medium enterprises in South Africa. Journal of Enterprising Culture, 22(3), 331-348.

23. Marshall, M. N. (1996). Sampling for qualitative research. Family practice, 13(6), 522-526.

24. Meyer, N. (2015). Poor People's Perceptions of Government Support for Entrepreneurship and Small Business Promotion in a Developing Country. Journal of Economics and Behavioral Studies, 7(6), 6-12.

25. Ndungu, K., and Theron, J. (2008). 'What Kind of Jobs?' Creating Opportunities for Decent Work. Unpublished report, NALEDI (Johannesburg) and Labour and EnterprisePolicy Research Group, University of Cape Town

26. Nkonki-Mandleni, B., and Anim, F. D. (2014). Determining factors of support for co-operatives in South Africa. Journal of Human Ecology, 47(2), 171-174.

27. Orobia, L. A., Byabashaija, W., Munene, J. C., Sejjaaka, S. K., and Musinguzi, D. (2013). How do small business owners manage working capital in an emerging economy? A qualitative inquiry. Qualitative Research in Accounting \& Management, 10(2), 127-143.

28. PMG. (2012). Access to funding by small enterprises: Commercial banks and Development Finance Institutions briefing. Retrieved from https://pmg.org.za/committee-meeting/14497 (accessed 06 April 2016).

29. Raap, P., and Mason, R. B. (2014). Project 2014/09: The nature of existing and emerging cooperatives in the wholesale and retail sector, Cape Peninsula University of Technology, Wholesale and Retail Leadership Chair, Cape Town.

30. Rowley, J. (2012). Conducting research interviews. Management Research Review, 35(3/4), 260-271.

31. Scherr, F. C., Sugrue, T. F., and Ward, J. B. (1993). Financing the small firm start-up: Determinants of debt use, The Journal of Entrepreneurial Finance, 3(1), 17.

32. Seed Academy. (2016). Seed Academy's Second Annual Startup Survey Results 2016 [Online]. Retrieved from http://www.fin24.com/Entrepreneurs/News/infographic-sa-entrepreneurs-are-not-creating-jobs-fast-enough20160629 (accessed: 24 August 2016).

33. Sibindi, A. B., and Aren, A. O. (2015). Is Good Corporate Governance Practice The Panacea For Small-ToMedium Businesses Operating In The South African Retail Sector? Corporate Ownership \& Control, 12(2/6), 579.

34. Snape, D., and Spencer, L. (2013). The Foundations of Qualitative Research. In Ritchie, J., Lewis, J., Nicholls, C. M. and Ormston, R. (Eds.), Qualitative research practice: A guide for social science students and researchers. (pp. 1-23). London, Sage.

35. South Africa. (1996). National Small Business Act No. 102 of 1996 . Retrieved from http://www.thedti.gov.za/sme_development/docs/act.pdf (accessed: 18 April 2015).

36. Statistics South Africa. (2015). Gross Domestic Product (GDP), 1st quarter 2015 . Retrieved from http://www.statssa.gov.za/publications/P0441/GDP_First_Quarter_2015_Presentation.pdf (accessed: 30 June 2015).

37. Steyn, J. (2013). Project 2013/01: Priority research needs of the South African Wholesale and Retail Sector, Cape Peninsula University of Technology, Wholesale and Retail Leadership Chair, Cape Town.

38. Timm, S. (2011). How South Africa can boost support to small businesses: lessons from Brazil and India. Retrieved from http://www.tips.org.za/files/india_brazil_2011_edit_s_timm.pdf (accessed: 22 June 2015).

39. Timm, S. (2016). Government red tape: Tripping over triplicate. Retrieved from http://www.financialmail.co.za/features/2016/03/03/government-red-tape-tripping-over-triplicate (accessed: 6 April 2016).

40. Vos, E., and Forlong, C. (1996). The agency advantage of debt over the lifecycle of the firm. The Journal of Entrepreneurial Finance, 5(3), 193.

41. W\&RSETA. (n.d.). The Premier Authority in Skills Development in the Wholesale and Retail Sector: brochure. Centurion, W\&RSETA.

42. W\&RSETA. (2013). Sector Skills Plan 2011-2016. 2013 Update. Retrieved from www.wrseta.org.za (accessed: 16 January 2014).

43. W\&RSETA. (2014). Sector Skills Plan Update 2014-2015. Retrieved from www.wrseta.org.za (accessed: 31 August 2015).

44. Weijland, H. (1992). Trade Networks for Flexible Rural Industry. Research-Memorandum, 1992-36, Amsterdam, Vrije Universiteit.

45. Zentes, J., Swoboda, B., and Foscht, T. (2012). Handelsmanagement [Retail Management], Vahlens Handbücher der Wirtschafts- und Sozialwissenschaften, 3rd ed., München, Vahlen. 